\title{
Are Gastrin-Cells Present in Mammalian Pancreatic Islets?
}

\author{
F. Lotstra, W. van der Loo and W. Gepts \\ Department of Pathology and Department of General Biology, Vrije Universiteit, Brussels, Belgium \\ Received: February 11, 1974, and in revised form: March 29, 1974
}

\begin{abstract}
Summary. The possible existence of gastrin-cells in the pancreas was investigated by a comparative immunohistological and immunochemical study of antral mucosa and pancreas of man, dog, rabbit, rat and pig. Gastrincells were identified in the antral mucosa of all these species with the indirect immunofluorescence and the immunoperoxidase methods. With the same methods, no gastrin-cells were detected in the pancreas in any of the species studied. With radioimmunoassay, serial dilutions of antral or duodenal extracts yielded curves
\end{abstract}

which were identical to those obtained with synthetic human gastrin, whereas pancreatic or islet extracts did not produce any significant displacement of the 125-Igastrin. Therefore, the presence of gastrin-producing cells in normal panereas remains questionable.

Key words: Gastrin, gastrin-cells, antral mucosa, pancreas, pancreatic islets, immunohistology, immunochemistry, staining characteristics of gastrin-cells.
The presence in the islets of Langerhans of insulinproducing B-cells and glucagon-producing A-cells is beyond any doubt, but the number as well as the function of other types of islet cells are still controversial. More specifically, a dispute remains whether gastrinelaborating cells exist in normal pancreatic islets. The main arguments in favour of gastrin-cells being present are:

1. The ulcerogenic tumours of the Zollinger-Ellison syndrome secrete gastrin $[1,2]$ and are composed of cells which exhibit the same morphological, tinctorial and cytochemical characteristics as the $D$ (or $A_{1}$ )-cells of pancreatic islets and as the gastrin-producing Gcells of the antral mucosa $[3,4,5,6,7]$.

2. With the electron-microscope, cells containing granules of a type similar to the G-cells of antral mucosa have been described in human islets of Langerhans $[3,8,9,10,11]$.

3. Several authors have been able to localize gastrin in the $D$ (or $A_{1}$ )-cells of pancreatic islets with immunofluorescent methods $[12,13,14]$ or to detect gastrin in extracts of pancreatic tissue with radioimmunoassay $[13,15]$.

However, none of these arguments has remained undisputed. Many of the cytochemical characteristics of the gastrin-producing G-cells are shared in common with other polypeptide-elaborating endocrine cells (the APUD system of Pearse [16]) and are therefore far from specific.

The tinctorial and ultrastructural identity of the cells composing the ulcerogenic islet-tumours with either $D$ (or $A_{1}$ ) pancreatic-cells or any other type of islet cells has been denied $[13,14,17,19]$. With bioassay methods, the demonstration of gastrin in normal mammalian pancreas has consistently failed $[1,20,21$, 22, 23, 24]. Even the immunochemical demonstration of gastrin-cells in the islets has been questioned: in a paper principally devoted to the gastrin-cells of the antral mucosa of man, Creutzfeldt et al. [18] state that they have been unable to demonstrate immunoreactive gastrin in human pancreas.

In view of these contradictory opinions, we thought it worthwhile to reinvestigate the presence of gastrin in the pancreas. In this paper we shall report $1^{\circ}$ the results of a comparative immunohistological study of the antral mucosa and of pancreatic islets in man, rat, dog, rabbit and pig; $2^{\circ}$ the results of a radioimmunoassay of gastrin in extracts of the pancreas of these species and in micro-dissected pancreatic islets of man.

\section{Material and Methods}

\section{Tissue Preparation}

The following tissues have been studied:

a) pieces of human pancreatic tissue obtained surgically ( 7 cases) or within four hours of death ( 22 cases); b) pieces of pancreatic tissue from rats [12], from dogs [8], from rabbits [7] and from pigs [2], excised immediately after sacrifice;

c) biopsies of human antral mucosa obtained either by oral biopsy tube or in the course of surgery for gastric or duodenal ulcer;

d) pieces of antral mucosa of rats, dogs, rabbits and pigs excised immediately after sacrifice.

For the demonstration of either gastrin or insulin with the immunofluorescence technique, the following methods of tissue processing were applied: unfixed or fixed (formalin, acetone, methyl alcohol or carbodiimide [25]) cryostat sections from fresh tissue, cryostat sections from formalin fixed tissue, paraffin sections from freeze-dried tissue, paraffin sections from formalin or carbodiimide [25] fixed tissue.

For the studies with peroxidase-labelled antibodies against either gastrin or insulin the specimens were fixed in Bouin's fluid and embedded in paraffin. 
Immunoassay of gastrin was performed in pancreatic tissue extracts from ten humans, seven dogs, seven rabbits, four rats and two pigs. Samples of pancreatic tissue weighing approximately $100 \mathrm{mg}$ were rapidly frozen in dry ice, weighed and homogenized in $0.15 \mathrm{M}$ $\mathrm{NaCl}-0.01 \mathrm{M}$ phosphate buffer $\mathrm{pH} 7.4$ (PBS), with the aid of an ultraturrax homogenizer. Thereafter the suspension was immediately boiled for five minutes and centrifuged at $2000 \mathrm{~g}$ for twenty minutes. The supernatant was preserved at $-20^{\circ} \mathrm{C}$. Other pieces of pancreatjc tissue or of antral mucosa were boiled in ten volumes of deionized water for sixty minutes, as prescribed by Greider and Me Guigan [13].
Freund's complete adjuvant. Cross immunoreactivity of the (SHG 2-17)-antibodies with cholecystokininpancreozymin (CCK-PZ) (lyophilized highly purified, obtained from GIH-Research Unit, Profs. J.E. Jorpes and V. Mutt, Karolinska Institutet, Stockholm, Sweden) occurred only at CCK-PZ concentrations above $25 \mathrm{mg} / \mathrm{ml}$ (Fig. 1). Furthermore the displacement of ${ }^{125}$ I was much more gradual with CCK-PZ than with SHG 2-17.

Antiinsulin serum was obtained from guinea-pigs repeatedly injected with solutions of three times recrystallized human insulin (kindly supplied by NOVO Industries), emulsified in complete Freund adjuvant.

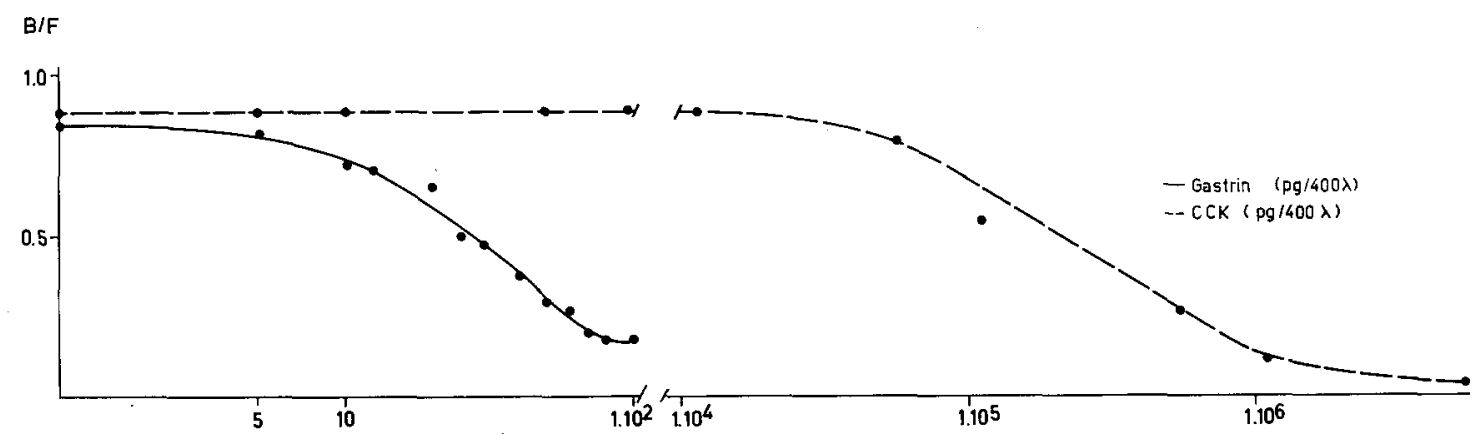

Fig. 1. Effect of increasing concentrations of synthetic human gastrin (SHG 2-17) or of pancreozymin-cholecystokinin (CCK) on the ratio between antibody-bound and free gastrin ${ }^{125} \mathrm{I}$ in the immunoassay system

Two large samples of human pancreatic tissue, obtained within $4 \mathrm{~h}$ of death and weighing approximately $20 \mathrm{~g}$, were cut in small pieces and boiled in deionized water, for sixty minutes. Thereafter, the suspension was lyophilized and the obtained powder was maintained under vacuum at $-20^{\circ} \mathrm{C}$. At the time of the radioimmunoassay the powder was diluted in PBS at $10 \mathrm{mg} / \mathrm{ml}$ and at $30 \mathrm{mg} / \mathrm{ml}$.

One sample of human pancreatic tissue, obtained during surgery, was rapidly frozen in liquid nitrogen. Sections $20 \mu$ thick were prepared in a cryostat and maintained in the vacuum at $-20^{\circ} \mathrm{C}$ until microdissection of the islets. The dissection was performed by free-hand under a dissecting microscope in a dry room. The samples were then weighed on a quartzfibre balance. Approximately $1.1 \mu \mathrm{g}$ of islet tissue was introduced in each vial. The gastrin-content of the material contained in each of the ten vials was assayed.

\section{Preparation of Antibodies to Gastrin}

Synthetic human gastrin I (residues 2-17) (SHG 2-17), obtained from Imperial Chemical Industries, was conjugated to rabbit serum albumin (RSA) (Miles), by means of carbodiimide, according to the method of Goodfriend et al. [26]. Amino-acid analysis with a Beckman autoanalyzer revealed that 8 molecules of SHG 2-17 were conjugated to one molecule of RSA. Three New Zealand white rabbits were immunized by injecting them four times, at three month intervals, with $2 \mathrm{mg}$ of conjugated SHG 2-17, emulsified in

\section{Staining Procedures}

For immunofluorescence microscopy, the indirect method of Coons et al. [27] was used. The sections were incubated for thirty minutes, in a moist chamber, at room temperature, in antigastrin or in antiinsulin serum, diluted 1:10 with phosphate buffered saline, $\mathrm{pH}$ 7.4. After washing in PBS, the sections were incubated in either fluorescein-labelled goat antirabbit serum (GAR-FITC, Nordic Immunochemicals) for gastrin demonstration or in fluorescein-labelled goat antiguinea-pig serum (GAGP-FITC, Nordic Immunochemicals) for insulin demonstration.

Peroxidase-labelled antibodies to gastrin or to insulin were prepared according to the method of Nakane and Pierce [28], slightly modified by Misugi et al. [29]. The peroxidase reaction was performed by the method of Graham and Karnorsky [30], except that postfixation in osmium tetroxide was omitted.

The following control reactions were applied: rabbit serum against SHG $2-17$ incubated for $24 \mathrm{~h}$ at $4^{\circ} \mathrm{C}$ with either an excess of SHG $2-17$ (50 ug per $\mathrm{ml}$ ), rabbit serum albumin $(1 \mathrm{mg} / \mathrm{ml})$ or cholecystokinin-pancreozymin $(50 \mu \mathrm{g}$ per $\mathrm{ml})$, serum from non-immunized rabbits, fluorescein-labelled goat antirabbit serum alone and peroxidase-labelled, non-specific antibodies. Equivalent control reactions were performed for the demonstration of insulin.

Ordinary staining procedures for light microscopy were also used: haematoxylin-eosin, lead haematoxylin [31], aldehyde-thionin [32], the Hellerström-Hellman- 
[33], Sevier-Munger- [34], and Grimelius [35] silver impregnation procedures.

\section{Radioimmunoassay of Gastrin}

Radioiodination of SHG 2-17 with ${ }^{125} \mathrm{I}$ was performed according to the method of Hunter and Greenwood [36], slightly modified. The reagents were all diluted in phosphate buffer, $0.5 \mathrm{M}, \mathrm{pH}$ 7.2. $2 \mu \mathrm{g}$ of SHG 2-17 were dissolved in $25 \mu \mathrm{l}$ of buffer and added to $1 \mathrm{me}$ of ${ }^{125} \mathrm{~T}$, followed by adding of $38 \mu \mathrm{g}$ of chloramine $T$ in $25 \mu$ l of buffer, $200 \mu \mathrm{g}$ of sodium metabisulfite in $100 \mu \mathrm{l}$ of buffer and $1 \mathrm{mg}$ of potassium iodide in $100 \mu \mathrm{l}$ of buffer. The radioiodination mixture was immediately applied to a Sephadex G-10 (Pharmacia Fine Chemicals) column (1.5 by $30 \mathrm{~cm})$ and eluted at room temperature with $0.1 \mathrm{M}$ potassium phosphate, $\mathrm{pH} 7.4$, in $1 \mathrm{ml}$ fractions. The specific activity measured between 200 and $400 \mathrm{mc}$ per $\mu \mathrm{g}$ of SHG $2-17$. The radioiodinated SHG $2-17$ was diluted in $0.15 \mathrm{M}$ $\mathrm{NaCl}, 0.01 \mathrm{M}$ phosphate buffer $\mathrm{pH}$ 7.4, containing $1 \%$ ovalbumin (Sigma, grade III) and $0.02 \%$ neomycin (Fradyl-A. Christiaens-Brussels). $50 \lambda$ of standard dilutions of SHG $2-17$ or $50 \lambda$ of serial dilutions of tissue extracts, were incubated with $300 \lambda$ of gastrinantiserum, diluted $1: 1500$, at $4^{\circ} \mathrm{C}$ for $24 \mathrm{~h}$. Subsequently $50 \lambda$ of a solution of ${ }^{125}$ I-SHG $2-17$ was added and the mixture was again incubated for $24 \mathrm{~h}$ at $4^{\circ} \mathrm{C}$. Separation of bound from unbound ${ }^{125 I-S H G ~ 2-~}$ 17 was obtained with the charcoal method of Herbert et al. [37], modified by Donald [38]. The unbound fraction was counted in a Packard autogamma-spectrometer. All the assays were performed in triplicate. The lower limit of sensitivity of our assay system, calculated from standard curves, is between 5 and $10 \mathrm{pg} /$ $\mathrm{ml}$.

\section{Results}

\section{Immunohistology}

Cells showing specific gastrin fluorescence (Figs. 2b, $6 \mathrm{a}$ and $7 \mathrm{a}$ ) or a positive peroxidase reaction (Fig. 3a) were numerous in all sections of formalin-fixed (for immunofluorescence) or Bouin-fixed (for immunoperoxidase technique) and paraffin embedded specimens of antral mucosa of man, dog, rabbit, pig and rat. In the first four species, they were localized in the midportion of the pyloric glands; in rat they were situated in the deeper portion of these glands. Specific gastrin fluorescence was not found in the antral mucosa with any of the other methods of tissue preparation (see material and methods).

The control reactions showed complete abolition of fluorescence and of the peroxidase reaction after blocking of the antibodies with an excess of SHG $2-17$. On the other hand, the fluorescence was unaffected by submitting the antibodies to rabbit serum albumin or to cholecystokinin-pancreozymin. No fluorescence or peroxidase reactions were obtained after incubation with serum from non-immunized rabbits, fluorescein- labelled goat antirabbit serum alone, or with peroxidase-labelled, non specific antibodies.

In contradistinction, irrespective of the method of tissue processing, specific gastrin immunofluorescence or a positive peroxidase reaction was never detected in any of the sections of pancreatic tissue, whether from man (Figs. $4 a$ and 5 a), rat, dog, rabbit or pig. A weak fluorescence was sometimes observed in some islet cells, but this was clearly due to auto-fluorescence of lipofuscin. On the other hand, a specific insulin immunofluorescence (Fig. $4 \mathrm{~b}$ ) and a positive insulin immunoperoxidase reaction (Fig. $5 \mathrm{~b}$ ) were regularly obtained in the islets of all the specimens of pancreatic tissue.

Sections of antral mucosa which were negative for insulin with immunofluorescence (Fig. 2a) were retested with antibodies against gastrin. Conversely, sections of pancreatic tissue in which gastrin cells could not be demonstrated (Fig. 4a) were retested with antibodies against insulin. In both cases, the results were positive (Figs. $2 \mathrm{~b}$ and $4 \mathrm{~b}$ ).

The G-cells of the antral mucosa reacted positively to lead haematoxylin (Figs. 6a and $6 \mathrm{~b}$ ). They were weakly argyrophilic with the Sevier-Munger technique (Figs. $7 \mathrm{a}$ and $7 \mathrm{~b}$ ), but did not stain with Grimelius and the Hellman-Hellerström techniques. The islet cells which stained positively for insulin, remained unstained with lead haematoxylin, but reacted positively to aldehyde-thionin.

\section{Radioimmunoassay}

A calibration diagram using $\mathrm{SHG} 2-17$ concentrations from 0 to $250 \mathrm{pg}$ per $400 \mu \mathrm{l}$ of incubation medium is shown in Fig. 8. Serial dilutions of antral and of duodenal mucosa yielded curves which did not differ from the standard curves of either SHG 2-17 or SHG 1-17.

On the other hand, serial dilutions of extracts of either fundal mucosa or of pancreatic tissue from man, rat and pig never caused any displacement of ${ }^{125} \mathrm{I}$ gastrin (Fig. 8). Neither was such a displacement obtained with samples of pure human islet tissue. A very small displacement of ${ }^{125}$ I-gastrin was observed in a few assays of dog and rabbit pancreatic tissue extracts, and in solutions of lyophilized extracts of large samples of human pancreatic tissue. However in all these cases, the figures calculated were close to the lower level of sensitivity of the assay system.

\section{Discussion}

Whereas our observations are in complete agreement with those in the literature concerning the presence of gastrin-secreting cells in the antral mucosal glands $[18,39,40,41,42,43,44,45,46,47]$, they are at variance with regard to the pancreas. In this gland, other authors have identified gastrin-containing cells with immunohistological methods $[12,13,14]$, as well as by radioimmunoassay of pancreatic tissue extracts 
$[13,15]$. With none of these methods have we been able to demonstrate gastrin in the pancreas of five mammalian species, including man. A similar negative finding has already been reported by Creutzfeldt et al. [18].

We have no ready explanation to offer for these discrepancies. In the first place methodological differences should be considered. Indeed, Greider and Mc Guigan [13], as well as Vassallo et al. [14] have stated explicitly that gastrin-immunofluorescence fails to appear in paraffin sections of formalin-fixed pancreatic tissue. However, the same method proves excellent for the demonstration of immunoreactive gastrin-cells in the gastric mucosa. Furthermore, as mentioned in "Material and Methods", we tried numerous other methods of tissue preparation, including fresh-frozen cryostat sections, as recommended by Greider and Mc Guigan [13] and by Vassallo et al. [14], but they all

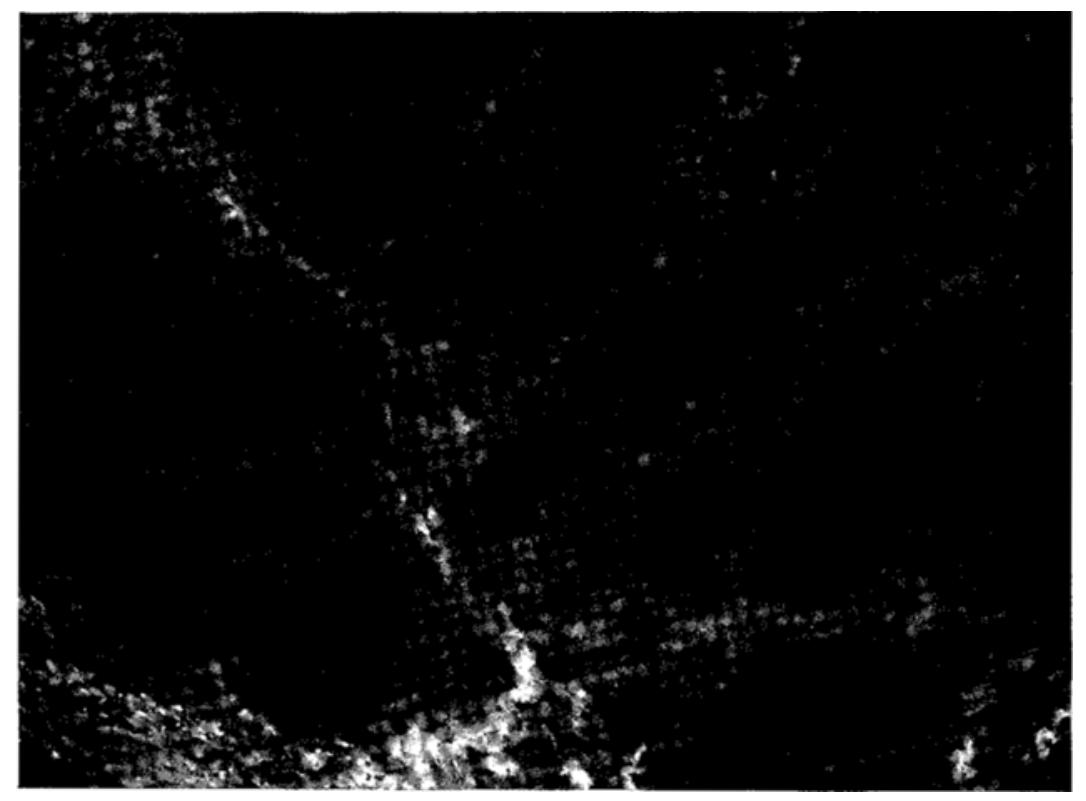

Fig. 2a. Section of formalin-fixed, paraffin-embedded normal human antral mucosa; indirect immunofluorescense method for the demonstration of insulin. No positive cells in the pyloric glands. $\times 400$

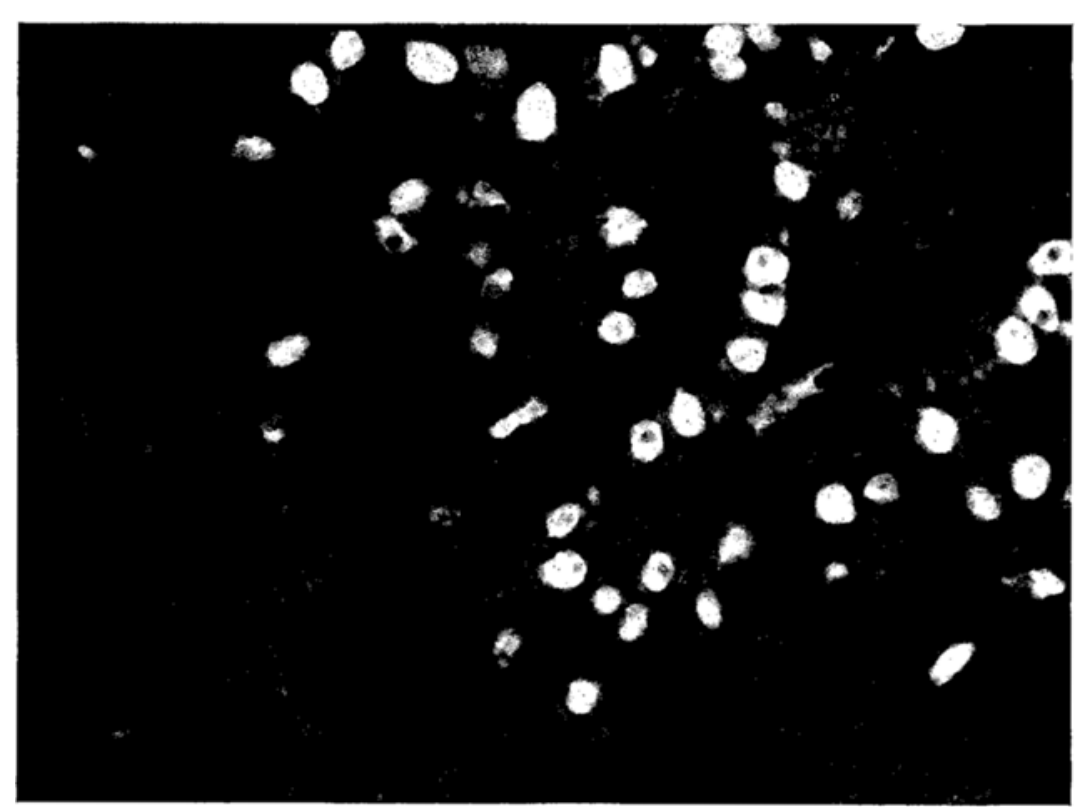

Fig. 2b. The same field as in Fig. 2a after restaining the section for gastrin (indirect immunofluorescence method). Numerous gastrin-cells are present in the pyloric glands. $\times 400$ 
yielded negative results. It should also be pointed out that Lomsky et al. [12] used formalin fixation and paraffin embedding for their successful demonstration of pancreatic gastrin cells with fluorescein-labelled antibodies.

The possible involvement of factors related to fixation is shown by the observation of Polak et al. [25]. These authors have pointed out that the demonstration with fluorescinated antibodies of glucagon-cells in the gastrointestinal tract, is wholly dependent on prior fixation with carbodiimide, whereas in the pancreatic islets, glucagon-cells can be demonstrated with a variety of fixatives and even in unfixed tissues. They contemplate the possibility that differences in behaviour between pancreațic and enteric glucagon may be due to a dissimilarity in their storage or precursor forms. Not less than five forms of gastrin have already been identified in serum and in tissue extracts: G13

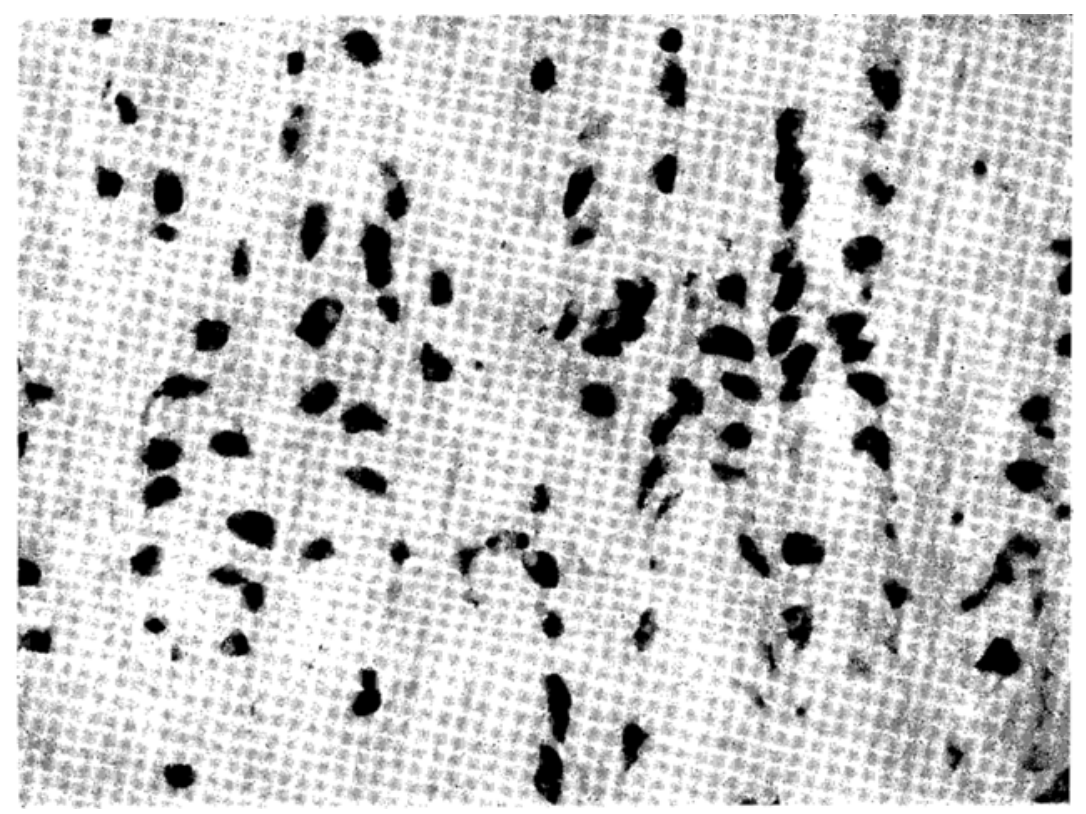

Fig. 3a. Gastrin-cells of the human antral mucosa demonstrated with the direct peroxidase-labelled antibody method on Bouin-fixed, paraffin-embedded tissue. $\times 400$

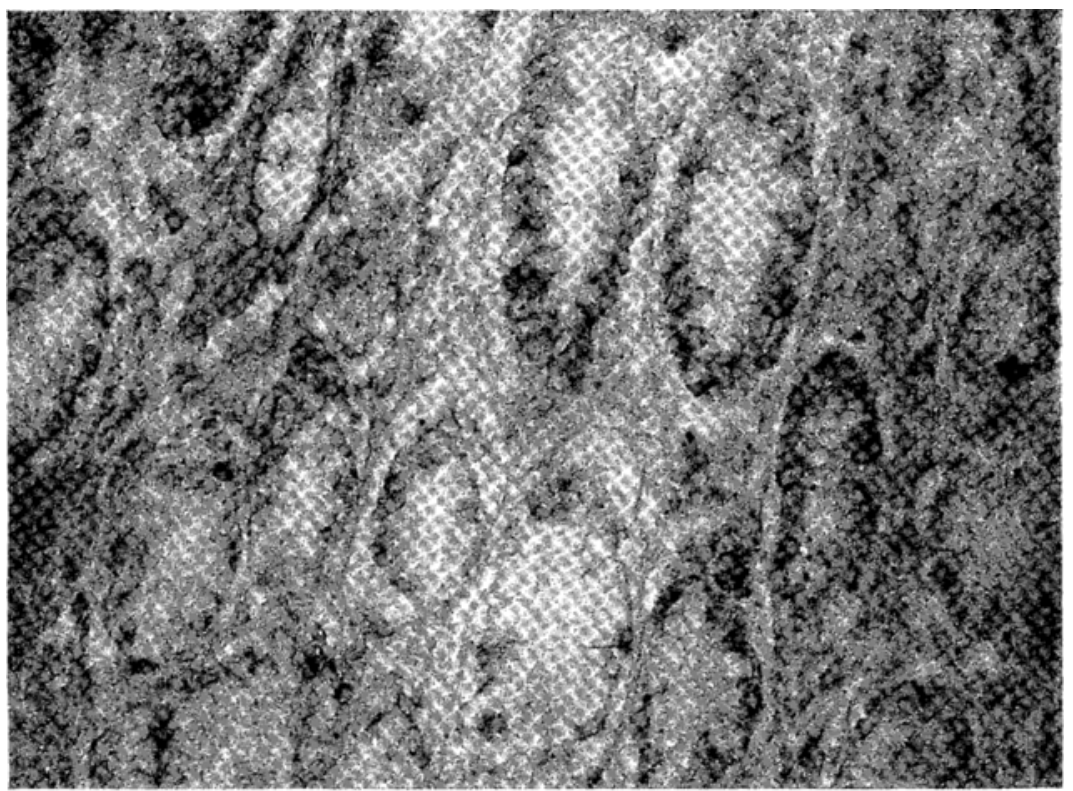

Fig. 3b. Section of human antral mucosa, Bouin-fixed and paraffin-embedded, stained for insulin with the direct peroxidase labelled insulin-antibody method. No positive cells in the pyloric glands. $\times 400$ 
(minigastrin), G17 (little gastrin), G 33 (big gastrin), component-I-gastrin, and "big-big" gastrin $[47,48$, $49,50,51,52,53,54,54 \mathrm{~b}]$. They differ in molecular size and can be separated by gel filtration. In our study, specific gastrin fluorescence also failed to appear in carbodiimide-fixed material, but this does not rule out the possibility that tissue preparation would affect differently the ability of the different storage forms of gastrin to bind gastrin-antibodies in tissue sections.
Even if factors related to tissue preparation should bear a part in the discrepant results obtained with immunohistochemical methods, they would not explain our failure to demonstrate gastrin with radioimmunoassay of pancreatic tissue extracts. Differences in extraction procedures cannot be implicated, because one of the methods used in our study is identical with that used by Greider and Mc Guigan [13], who identified significant amounts of gastrin in samples of human

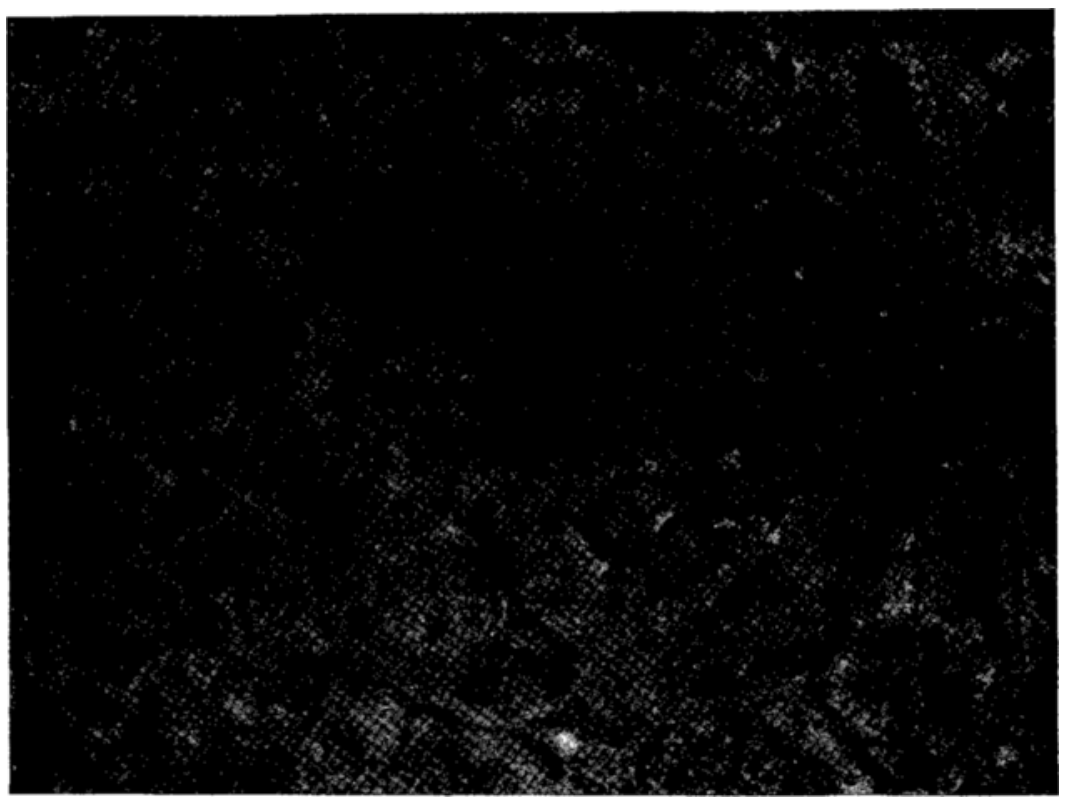

Fig. 4a. Human pancreas, formalin-fixed and paraffin-embedded; indirect immunofluorescence method for gastrin. No specific fluorescence in the islet or acinar tissue. $\times \mathbf{4 0 0}$

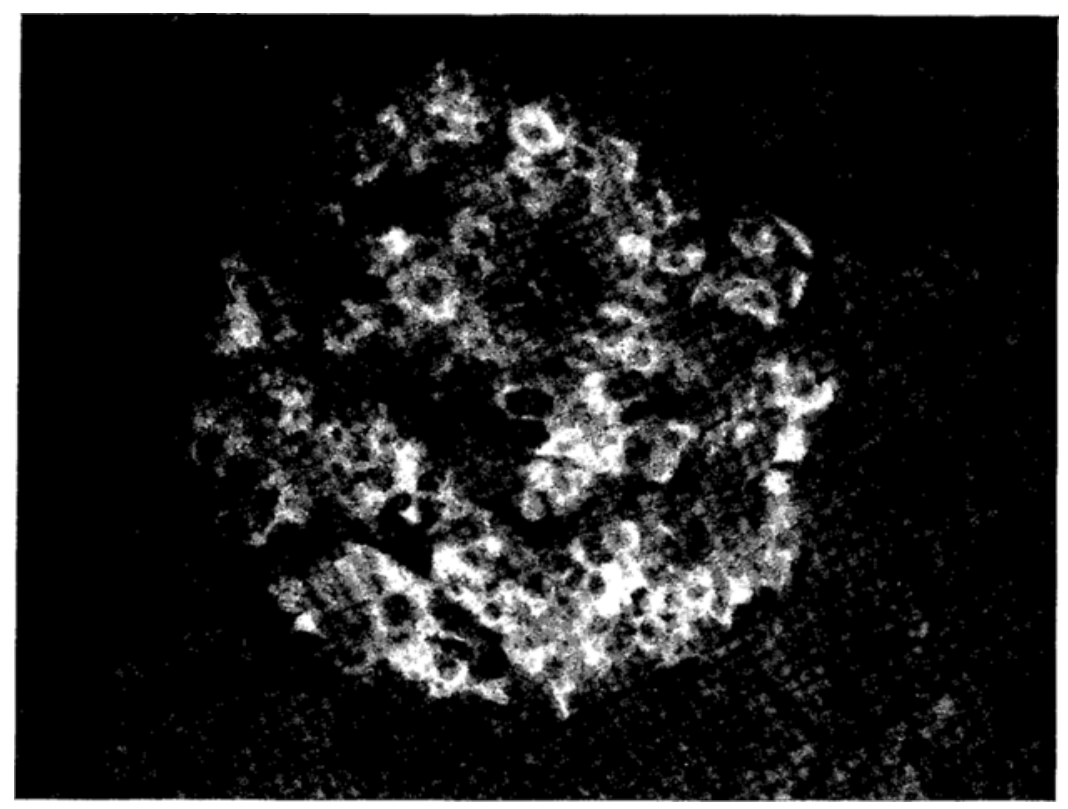

Fig. 4b. The same field as in Fig. 4a after restaining for insulin with the indirect immunofluorescence method for insulin. Positive staining of numerous islet cells. $\times 400$ 
pancreatic tissue. Neither can this discrepancy be attributed to a lack of sensitivity of our assay system. The lower limit of gastrin concentration which it is able to detect is approximately $3 \mathrm{pg}$ per $\mathrm{mg}$ wet weight pancreatic tissue, a figure well below the values of gastrin-content reported by Greider and Mc Guigan $(42$ to $110 \mu \mathrm{g} / \mathrm{mg})$ [13]. It is true that in a few assays of pancreatic tissue extracts from man, dog and rabbit a small displacement of ${ }^{125} \mathrm{I}$-gastrin was observed in the assay system, but the figures were so close to the lower limit of detection as to be of questionable significance.

Although our study does not entirely rule out the possible presence of gastrin-producing cells in the pancreas of mammals, it suggests that, if present, they must be in such small number as to be of limited physiological significance. Taking into consideration the common embryological origin of all islet cells and perhaps of all polypeptide elaborating cells $[16]$, the

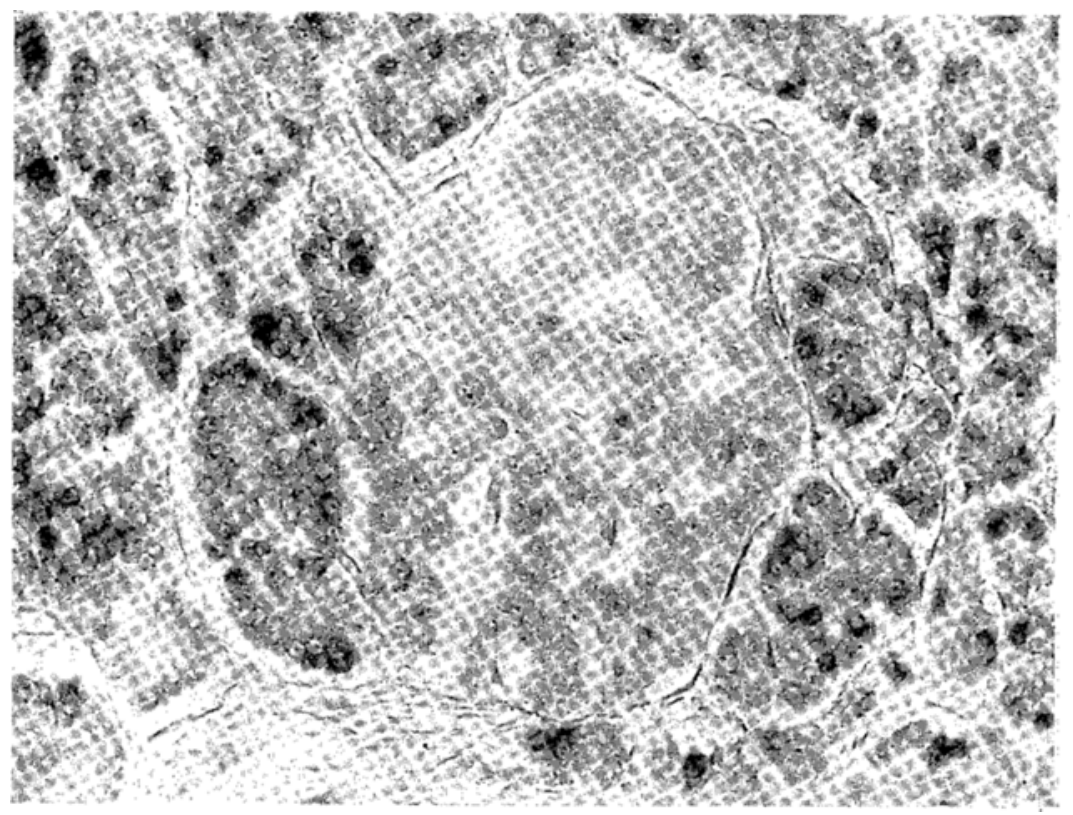

Fig. 5a. Human pancreas, Bouin-fixed and paraffin-embedded, stained for gastrin with the direct peroxidase-labelled antibody method. Negative results. $\times 400$

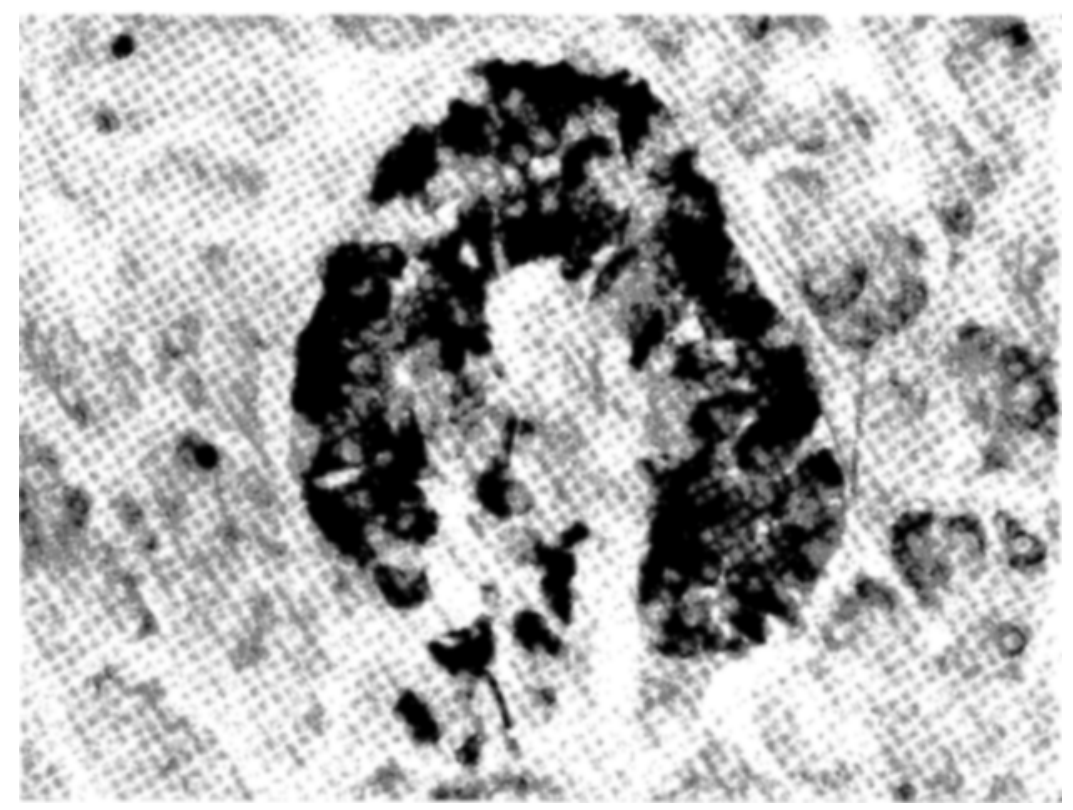

Fig. 5b. Human pancreas, Bouin-fixed and paraffin-embedded, stained for insulin with the direct peroxidase-labelled antibody method. Positive staining of numerous islet cells. $\times 400$ 
occasional presence of a few gastrin cells in a pancreas would not be surprising. In this respect, it is noteworthy that Hansky et al. [55] were unable to demonstrate gastrin cells with the immunofluorescence technique in the pancreas of three of four dogs; in the fourth, they found a small number of fluorescent cells, but only in the tail of the pancreas. Even less surprising would be the appearance of gastrin-cells in the pancreas under pathological circumstances.
The latest studies on the ultrastructure of the pancreatic islets $[56,57,58,59,60]$ leave little doubt that cells other than insulin- and glucagon producing cells are present in these islets. In a previous publication $[10]$, our group has identified two other types of islet cells, which were designated provisionnally as types III and IV. Four types of islet cells have also been admitted by the revised Wiesbaden classification of gut endocrine cells [61]. However, our previous sug-

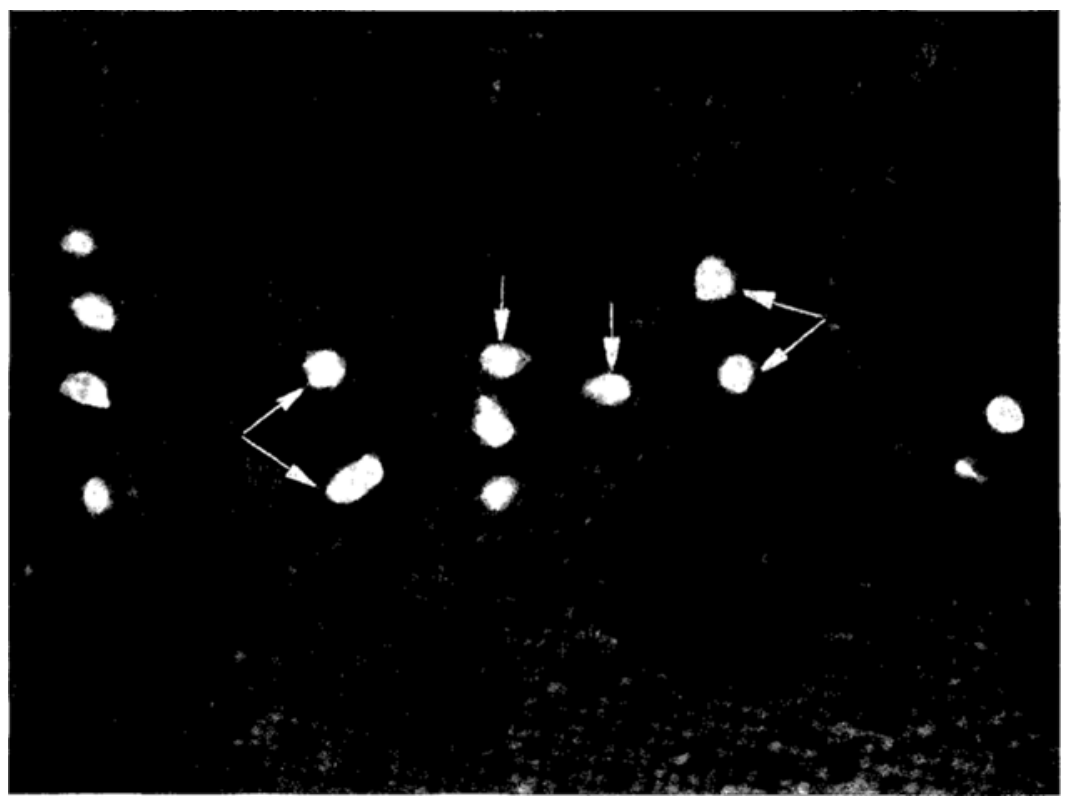

Fig. 6a. Section of formalin-fixed, paraffin-embedded human antral mucosa; indirect immunofluorescence method for gastrin. $\times 400$

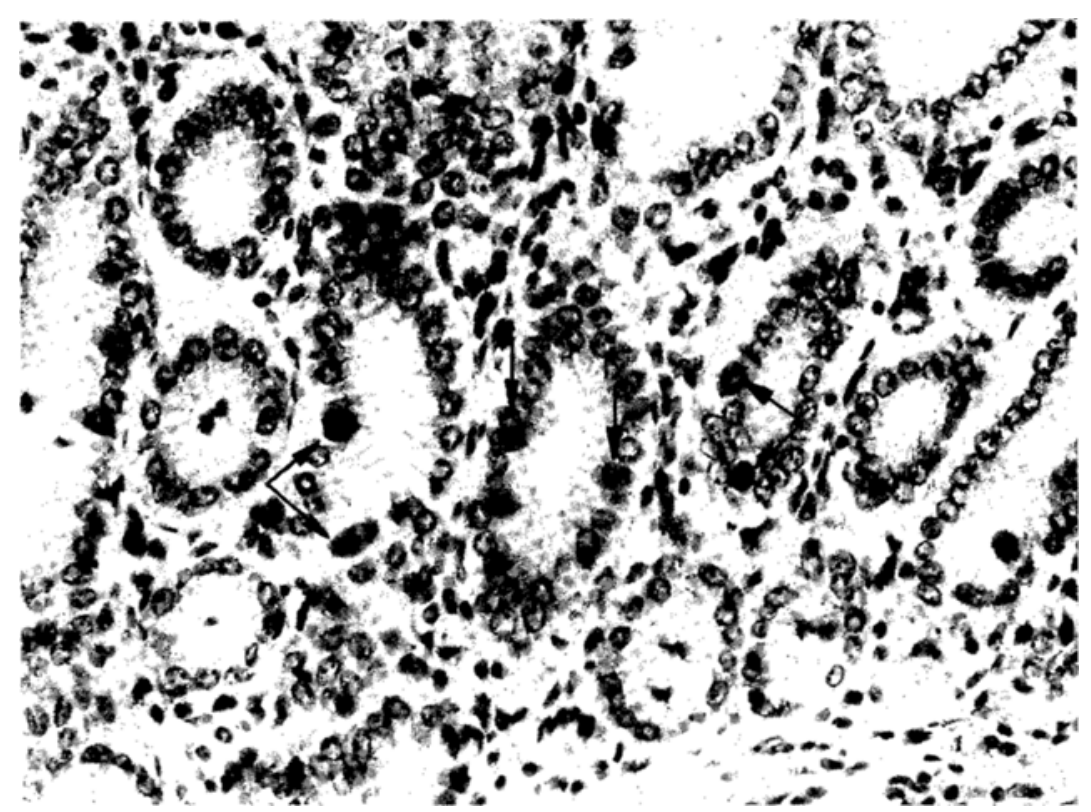

Fig. 6b. The same field as in Fig. 6a after restaining with lead-hematoxylin. The fluorescent cells of Fig. 6a have taken up the lead-hematoxylin stain. $\times 400$ 
gestion that type III-cells might be equivalent to the gastrin-secreting cells of the antral mucosa is not born out by the present study. Indeed, the ultrastructural characteristics of these cells resemble much more those of D-cells [62]. The function of the latter cells still remains unknown, but the fact that they are present also in the normal fundus mucosa $[63,64]$, where no gastrin can be detected, makes it doubtful that they secrete gastrin.
One of the arguments that has been put forward in favour of gastrin-cells being present in the pancreatic islets of man, is the existence of islet cell tumours which secrete gastrin (Zollinger-Ellison syndrome). While tumours of endocrine glands usually perform some task of their parent tissue, this is not always the case, and several examples have been published recently of islet tumours which, besides insulin or glucagon, seem to manufacture hormoned entirely different from those

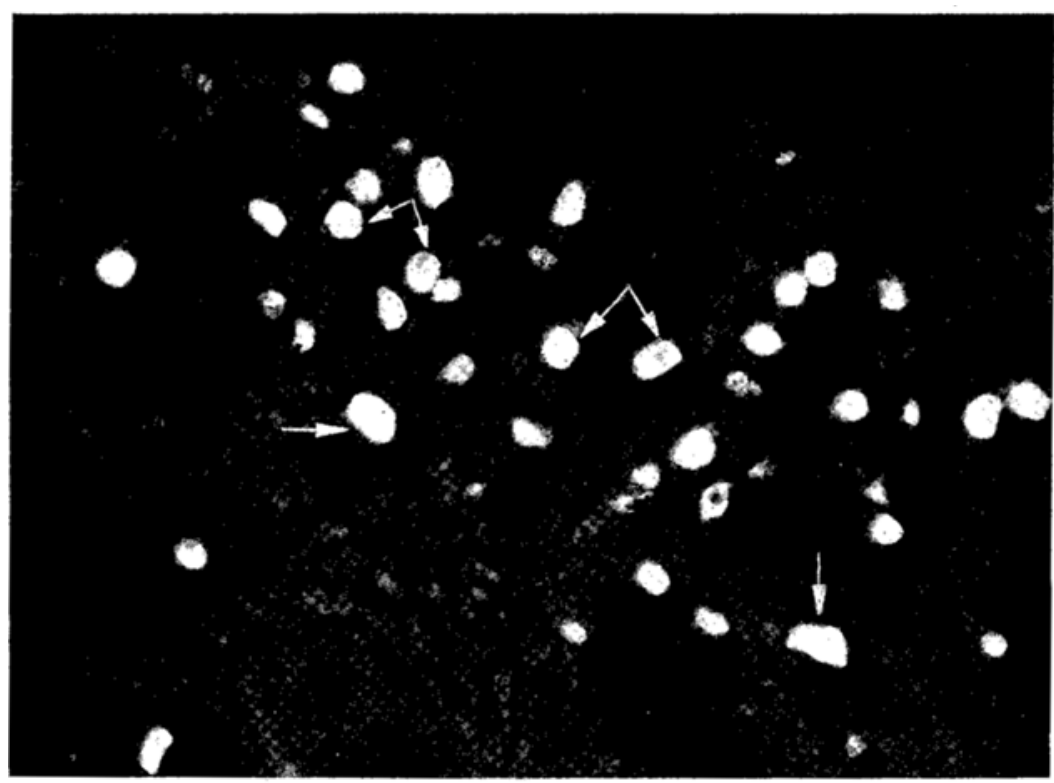

Fig. 7a. Section of formalin-fixed, paraffin-embedded human antral mucosa; indirect immunofluorescence method for gastrin. $\times 420$

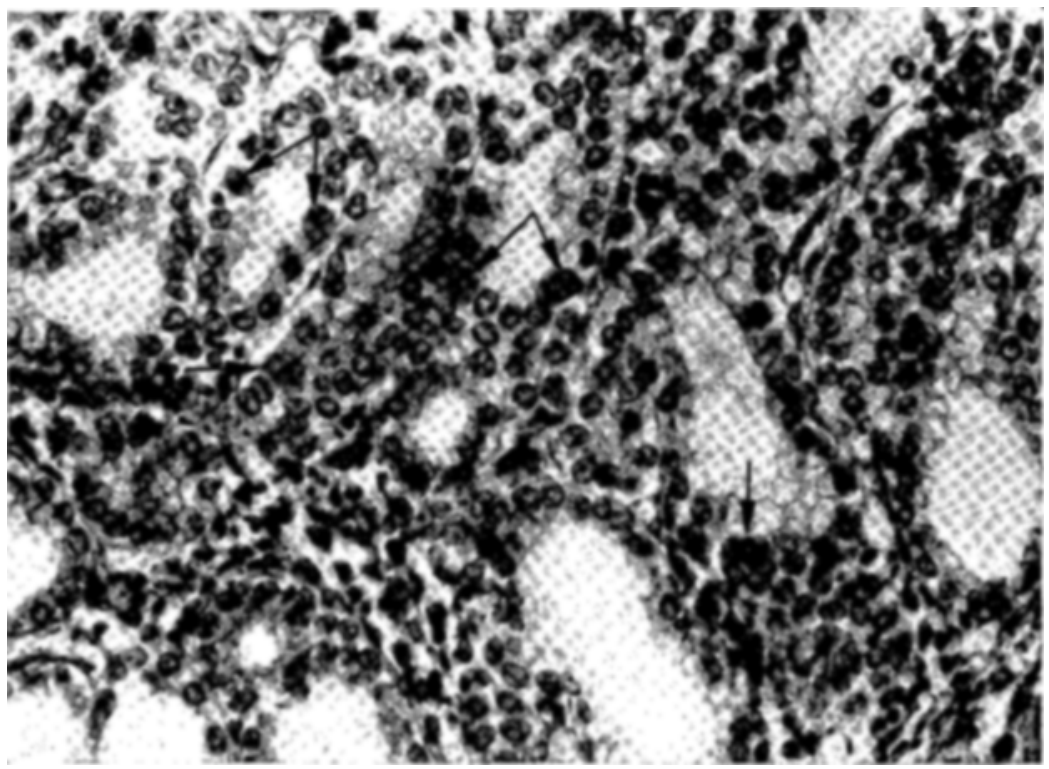

Fig. 7b. The same field as in Fig. 7a, after restaining with the Sevier-Munger silver nitrate technique. The fluorescent cells of 6 a are weakly argyrophilic. $\times 420$ 
produced by normal islets $[65,66,67]$. The secretion of gastrin by the ulcerogenic tumours of the ZollingerEllison syndrome is beyond doubt $[1,2]$. However, the ultrastructural identity of the cells composing these tumours with $\mathrm{D}$ or $\mathrm{A}_{1}$-cells of the pancreatic islets has been questioned $[11,14,18,19]$. Gastrin-secretion may well be a characteristic newly acquired by tumoral islet cells, but in the light of present study, it cannot be concluded that gastrin-cells are regular components of normal mammalian pancreatic islets. cytologique du pancréas endocrine, tumoral et nontumoral dans le syndrome de Zollinger-Ellison. Rev. int. Hépatol. 16, 737-761 (1966)

5. Cavallero, C., Solcia, E., Sampietro, R.: Cytology of islet tumours and hyperplasias associated with the Zollinger-Ellison syndrome. Gut 8, 172-177 (1967)

6. Becker, V., Seelig, H.P.: Pathologic anatomy and pathophysiology of the Zollinger-Ellison syndrome. In: Non-Insulin Producing Tumours of the Pancreas: Modern Aspects on Zollinger-Ellison Syndrome and Gastrin, pp. 49-60 (Eds. Demling, L. and Ottenjahn, R.). Stuttgart: Thieme 1969

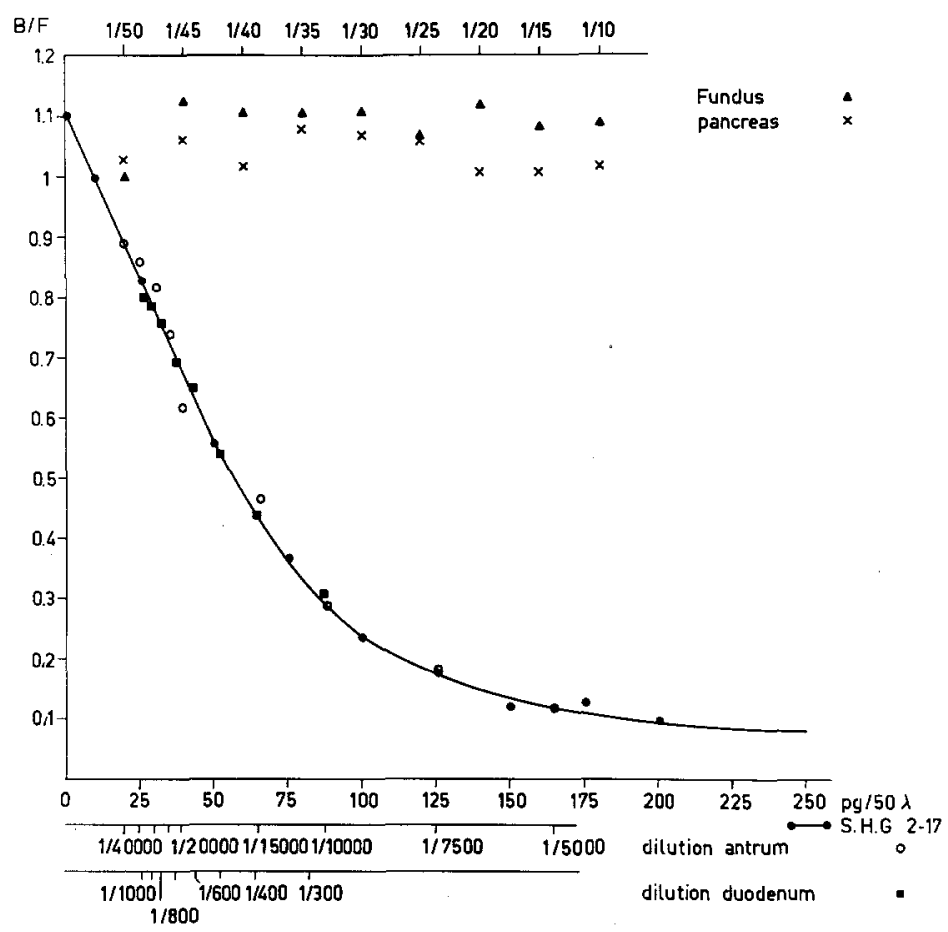

Fig. 8. Immunoassay calibration curve of synthetic human gastrin (SHG 2-17) against extracts of human antral or duodenal mucosa, and against extracts of human fundal mucosa or pancreas. No difference was observed when SHG $1-17$ was used for calculation of the calibration curve in stead of SHG $2-17$

Acknowledgement. This work was supported by grant 1190 of the Belgian Foundation for Scientific Medical Research. The authors wish to thank Mrs. N. Buelens, Miss. Ch. Arijs, Mr. Cl. Cortier, Mrs. Soffers and Mrs. E. Willems for their excellent technical assistance.

\section{References}

1. Gregory, R.A., Tracy, H.J., French, J.M., Sircus, W.: Extraction of gastrin-like substance from pancreatic tumour in a case of Zollinger-Ellison syndrome. Lancet 1960 I, 1045-1048

2. Gregory, R.A., Tracy, H.J., French, J.M., Sircus, W.: Extraction of gastric secretagogue in Zollinger-Ellison tumours. Lancet 1967 II, $543-544$

3. Solcia, E., Sampietro, R.: On the nature of the metachromatic cells of pancreatic islets. Z. Zellforsch. 65, $131-138(1965)$

4. Potet, F., Martin, E., Thiery, J.P., Bader, U.P., Bonfils, S., Lambling, A.: Etude histologique et
7. Sehmidt, H.A., Riecken, O.: Histochemical studies on Zollinger-Ellison syndrome. In: Non-Insulin Producing Tumours of the Pancreas: Modern Aspects on Zollinger-Ellison Syndrome and Gastrin, pp. 6577 (Eds. Demling, L. and Ottenjahn, R.). Stuttgart: Thieme 1969

8. Solcia, E., Sampietro, R.: Cytologic observations on the pancreatic islets with reference to some endocrinelike cells of the gastro-intestinal mucosa. Z Z Zellforsch. 68, $689-698(1965)$

9. Thiery, J.P., Bader, J.P.: Ultrastructure des ilôts de Langerhans du pancréas humain normal et pathologique. Ann. Endocr. (Paris) 27, 625-647 (1966)

10. Deconinck, J., Potvliege, P.R., Gepts, W.: The ultrastructure of the human pancreatic islets. I. The islets of adults. Diabetologia 7, 266-282 (1971)

11. Like, A.A., Orci, L.: Embryogenesis of the human pancreatic islets: A light and electron microscopic study. Diabetes 21 (suppl. 2), 511-534 (1972)

12. Lomsky, R., Langr, F., Vortel, V.: Immunochemical demonstration of gastrin in mammalian islets of Langerhans. Nature 223, 618-619 (1969) 
13. Greider, M.H., Mc Guigan, J.E.: Cellular localization of gastrin in human pancreas. Diabetes 20, 389-396 (1971)

14. Vassallo, G., Solcia, E., Bussolati, G., Polak, J.M., Pearse, A.G.E.: Non G๓cell gastrin-producing tumours of the pancreas. Virchows Arch. Abt. B Zellpath 11, 66-79 (1972)

15. Nilsson, G., Yalow, R.S., Berson, S.A.: Distribution of gastrin in the gastro-intestinal tract of human, dog, cat and hog. Symposium on Frontiers in Gastrointestinal Hormone Research (Special Nobel Symposia Series). Quoted by Berson, S.A., Yalow, R.S. Radioimmunoassay in Gastroenterology. Gastroenterology 62, 1061-1084 (1972)

16. Pearse, A.G.E.: Common cytochemical and ultrastructural characteristics of cells producing polypeptide hormones (The APUD Series) and their relevance to the thyroid and ultimobranchial C-cells and calcitonin. Proc. roy. Soc. B 170, 71-80 (1968)

17. Creutzfeldt, W., Creutzfeldt, C., Perings, E.: Light and electron microscopic findings in three clinical cases of the Zollinger-Ellison syndrome. In: NonInsulin Producing Tumours of the Pancreas: Modern Aspects on Zollinger-Ellison Syndrome and Gastrin, pp. 86-99 (Eds. Demling, L. and Ottenjahn, R.). Stuttgart: Thiome 1969

18. Creutzfeldt, W., Arnold, R., Creutzfeldt, C., Feurle, G., Ketterer, H.: Gastrin and G-cells in the antral mucosa of patients with pernicious anaemia, acromegaly and hyperparathyroidism. and in a ZollingerEllison tumour of the pancreas. Europ. J. clin. Invest. 1, 641 -479 (1971)

19. Munger, B.L.: The biology of secretory tumours of the pancreatic islets. In: Handbook of Physiology. Section 7. Endocrinology - vol. 1, p. 308 (Eds. Steiner, D.F. and Freinkel, N.). Washington: American Physiological Society 1972

20. Osborne, M.P., Brown, M.E., Le Compte, P.M.: Ulcerogenic non-beta cell pancreatic islet carcinoma: Studies on the extraction and assay of a possible secretagogue. Amer. J. Surg. 100, 48-53 (1960)

21. Osborne, M.P., Pernokas, L.N., Brown, M.E. Studies on the preparation and nature of a gastric secretagogue of pancreatic origin. New Engl. J. Med. $268,465-468$ (1963)

22. Hallenbeck, G.A., Code, C.F., Mesbrath, D.C. Absence of demonstrable gastric secretagogue in normal pancreatic tissue. Gastroenterology 44, 627$630(1963)$

23. Jackson, R.H., Blair, E.L., Dawson, P.J., Reed, J.D., Watts, W.P.T.: Gastrin activity of tumour tissue in a child with the Zollinger-Ellison syndrome. Lancet 1963 II, 908-912

24. Elliott, D.W., Endahl, G.L., Zollinger, R.M. : Gastrin-like activity in the human pancreas. Gastroenterology 46, 740, (1964)

25. Polak, J.M., Bloom, S., Coulling, I., Pearse, A.G.E.: Immunofluorescent localisation of enteroglucagon cells in the gastro-intestinal tract of the dog. Gut 12, $311-318(1971)$

26. Goodfriend, T.L., Levine, L., Fasman, C.B.: Antibodies to bradykinin and angiotensin: A use of carbodiimide in immunology. Science 144, 13441346 (1964)

27. Coons, A.H., Leduc, E.H., Connolly, J.M.: Studies on antibody production. I. A method for the histochemical demonstration of specific antibody and its application to a study of the hyperimmune rabbit. J. exp. Med. 102, 49-60 (1955)

28. Nakane, P.K., Pierce, G.B., jr.: Enzyme labelled antibodies for the light and electron microscopic localisation of tissue antigens. J. cell. Biol. 33, 307$318(1967)$
29. Misugi, K., Howell, S.L., Greider, M.H., Lacy, P.E., Sorenson, G.D.: The panereatic B-cell. Demonstration with peroxydase labelled antibody technique. Arch. Path. 89, 97-102 (1970)

30. Graham, R.C., Karnovsky, M.J.: The early stages of absorption of injected horseradish peroxydase in the proximal tubules of mouse kidney: ultrastructural cytochemistry by a new technique. J. Histochem. Cytochem. 14, 291-302 (1966)

31. Solcia, E., Capella, C., Vassallo, G.: Lead haematoxylin as a stain for endocrine cells. Histochemie 20, 116-126 (1969)

32. Paget, G. E.: Aldehyde-thionin. A stain having similar properties to aldehyde-fuchsin. Stain Technol. 95, $223-226(1954)$

33. Hellerström, C., Hellman, B.: Some aspects of silver impregnation of the islets of Langerhans in the rat. Acta endocr. (Kbh.) 35, 518-532 (1960)

34. Sevier, A.C., Munger, B.L.: Technical note. A silver method for paraffin sections of neural tissue. J. Neuropath. exp. Neurol. 24, 130-135 (1965)

35. Grimelius, L.: A silver nitrate stain for $\alpha_{2}$ cells in human pancreatic islets. Acta Soc. Med. upsalien. $73,243-270$ (1968)

36. Hunter, W.M., Greenwood, F.C.: Preparation of 131iodine labelled human growth hormone of high specific activity. Nature 194, 495-496 (1962)

37. Herbert, V., Lon, K.S., Gottlieb, C. W., Bloicher, S. J. : Coated charcoal assay of insulin. J. clin. Endocr. 25, 1375-1384 (1965)

38. Donald, R.A.: Application of the coated charcoal separation to the radioimmunoassay of plasma corticotrophin. J. Endocr. 41, 499-508 (1968)

39. Solcia, E., Sampietro, R.: Cytologic observations on pancreatic islets with reference to some endocrinelike cells of the gastro-intestinal mucosa. Z. Zellforsch. 68, 689-698 (1965)

40. Solcia, E., Vassallo, G., Sampietro, R.: Endocrine cells in the antropyloric mucosa of the stomach. Z. Zellforsch. 81, 474-486 (1967)

41. Solcia, E., Vassallo, G., Capella, C.: Studies on the G-cells of the pyloric mucosa, the probable site of gastrin secretion. Gut 10, 379-388 (1969)

42. Me Guigan, J.E.: Gastric mucosal intracellular localisation of gastrin by immunofluorescence. Gastro. enterology 75, 315-327 (1968)

43. Bussolati, G., Pearse, A.G.E.: Immunofuorescent localisation of the gastrin-containing $\mathrm{G}$-cells in the pyloric antrum of the pig. Histochemie 21, 1-4 (1970)

44. Pearse, A.G.E., Bussolati, G.: Immunofluorescence studies of the distribution of gastrin cells in different clinical states. Gut 11, 646-648 (1970)

45. Mitschke, H.: Vergleichende immunhistologische und cytochemische Untersuchungen der Gastrinzellen beim Menschen. Virchows Arch. Abt. A path. Anat. 353, 347-359 (1971)

46. Greider, M.H., Steinberg, V., Mc Guigan, J.E.: Electron microscopic identification of the gastrin cell of the human antral mucosa by means of immunocytochemistry. Gastroenterology 63, 572-583 (1972)

47. Berson, S.A., Yalow, R.S.: Nature of immunoreactive gastrin extracted from tissues of gastro-intestinal tract. Gastroenterology 60, 215-222 (1971)

48. Yalow, R.S., Berson, S.A.: Size and charge distinctions between endogenous human-plasma gastrin in peripheral blood and heptadecapeptide gastrins. Gastroenterology 58, 609-615 (1970)

49. Yalow, R.S., Berson, S.A.: Further studies on the nature of immunoreactive gastrin in human plasma. Gastroenterology 60, 203-214 (1971)

50. Yalow, R.S., Berson, S.A.: And now big big gastrin. Biochem. biophys. Res. Commun. 48, 391-395 (1972) 
51. Gregory, R.A., Tracy, H.J.: Isolation of two „Big gastrins $^{\text {"6 }}$ from . Zollinger-Ellison tumour tissue. Lancet 1972 II, 797-799

52. Rehfeld, J.F.: Three components of gastrin in human serum. Biochem. biophys. Acta 285, 364-372 (1972)

53. Rehfeld, J.F., Stadil, F.: "Big gastrins" in ZollingerEllison syndrome. Lancet 1972 II, 1200

54. Yalow, R.S., Wu, N.: Additional studies on the nature of big big gastrin. Gastroenterology 65, 19-27 (1973)

$54 b$. Rehfeld, J.F.: Gastrins in serum. A review of gastrin radioimmunoanalysis and the discovery of gastrin heterogeneity in serum. Scand. J. Gastroent. 8, 577$583(1973)$

55. Hansky, J., Mc Naughton, J., Navin, R.C.: Distribution of $\mathrm{G}$-cells in the canine gastro-intestinal tract. Aust. J. emp. biol. med. Sci. 50, 391 - 394 (1972)

56. Sato, F., Herman, L., Fitzgerald, P.J.: The comparative ultrastructure of the pancreatic islets of Langerhans. Gen. comp. Endocr. 7, 132-155 (1966)

57. Thiery, J.P., Bader, J.P.: Ultrastructure des ilôts de Langerhans du paneréas humain normal et pathologique. Ann. Endocr. 27, 625-647 (1966)

58. Björkman, N., Hellerström, C., Hellman, B., Peterssen B.: The cell types in the endocrine pancreas of the human fetus. Z. Zellforsch. 72, 425-445 (1966)

59. Greider, M.H., Bencosme, S.A., Lechago, J.: The human pancreatic islet cells and their tumours. I. The normal pancreatic islets. Lab. Invest. 22, 344$345(1970)$

60. Deconinck, J., Van Assche, F.A., Potvliege, P.R. Gepts, W.: The ultrastructure of the human pancreatic islets. II. The islets of neonates. Diabetologia 8, 326-333 (1972)

61. Solcia, E., Pearse, A. G.E., Grube, D., Kobayashi, S., Bussolati, G., Creutzfeldt, W., Gepts, W.: Revised
Wiesbaden classification of gut endocrine cells. Rendic. Gastroenterol. 5, 13-16 (1973)

62. Pearse, A.G.E., Solcia, E., Forssman, W.G.: In: Origin, chemistry, physiology and pathophysiology of the gastro-intestinal hormones. $W$. Creutzfeldt (ed.) p. 95. Stuttgart, New York: F.K. Schattauer Verlag 1970

63. Forssman, W.G., Orci, L.: Ultrastructure and secretory cycle of the gastrin-producing cell. $Z$. Zellforsch. 101, 419-432 (1969)

64. Forssman, W.G.: Ultrastructure of hormone-producing cells of the upper gastro-intestinal tract. In: Origin, chemistry, physiology and pathophysiology of the gastro-intestinal hormones, pp. 31-70 (Ed. W. Creutzfeldt). Stuttgart, New York: Schattauer 1970

65. Law, D.H., Liddle, G.W., Scott, H.W. jr., Tauber, S.D.: Ectopic production of multiple hormones (ACTH, MSH and gastrin) by a single malignant tumour. New Engl. J. Med. 273, 292-296 (1965)

66. O'Neal, L.W., Kipnis, D.M., Lase, S.A., Lacy, P.E., Jarrett, L.: Secretion of various endocrine substances by ACTH-secreting tumours - gastrin, melanotrophin, norepinephrine, serotonin, parathormone, vasopressin, glucagon. Cancer (Philad.) 21, 1219$1232(1968)$

67. Sircus, W., Brunt, P.W., Walker, R.J., Small, W.P., Falconer, C.W.A., Thomson, Ch. G.: Two cases of ,pancreatic cholera" with features of peptide secreting adenomatosis of the pancreas. Gut 11, 197-205 (1970)

Professor W. Gepts

Dept. of Pathology

Brugman University Hospital

4, Place Van Gehuchten

B-1000 Brussels

Belgium 